BACTERIOLOGICAL NOMENCLATURE

$A$ N D

TAXONOMY

Volume 11

\title{
CLASSIFICATION OF THE KLEBSIELLA-AEROBACTER GROUP WITH SPECIAL REFERENCE TO THE COLD-TOLERANT MESOPHILIC AEROBACTER TYPES
}

\section{Michael Grimes}

\section{Dairy and Food Microbiology Department University College, Cork, Ireland}

SUMMARY: Aërobacter liquefaciens Grimes and Hennerty 1931 is a laterillegitimate homonym of A. liquefaciens Beijerinck l900. A. lipolyticus nom. nov. is proposed in its place. A detailed description is given. A. lipolyticus is widely distributed in nature and is important in dairy science. It usually fails to produce gas from lactose at $37^{\circ} \mathrm{C}$, but produces it abundantly at $20-30^{\circ} \mathrm{C}$. A. ärogenes with which it may be confused, produces gas from lactose at $37^{\circ} \mathrm{C}$. A. lipolyticus differs from A. hibernicus by $\overline{l i q u e f a c t i o n}$ of gelatin.

Since Escherich (1885) published his paper on "Intestinal Bacteria" and Beijerinck (1900) described and named Aerobacter aërogenes, the classification of the taxa of the family Enterobacteriaceae has been a subject for investigation, discussion and review. The different viewpoints on the interrelationships of the genera Klebsiella and Aerobacter are discussed in the 7 th edition (1957) of Bergey's Manual of Determinative Bacteriology, the International Bulletin of Bacteriological Nomenclature and Taxonomy founded in 1951 and in many papers published in the various journals dealing with bacteriology, microbiology and public health.

The Enterobacteriaceae Subcommittee (originally The Salmonella Subcommittee) and the Judicial Commission and their members collectively and individually have expressed their viewpoints in a series of papers in the International Bulletin.

(Page 111) 
Kauffmann and Edwards (1952) emended the description of Klebsiella to include nonmotile, nonliquefying, Gramnegative rods, fermenting lactose and mannitol, citrate positive and urea negative, or late and irregularly positive, and named two species, $\underline{K}$. pneumoniae and $\underline{K}$. rhinoscleromatis. They stated:

"It is realized that no provision is made for the motile forms classified as Aërobacter. It is felt that present knowledge of the se forms is insufficient to justify their placement in a definite group."

Edwards and Fife (1955) studied 856 cultures of Klebsiella and Aerobacter and stated that no single biochemical test or combination of tests sufficed clearly to distinguish the genus

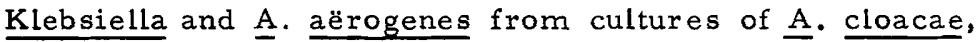
and that many aberrant and intermediate strains occurred. It was suggested that the nonmotile forms which do not liquefy gelatin be placed in the genus Klebsiella, and that Aerrobacter be redefined as a motile liquefying group with $\mathrm{A}$. cloacae as the type. With regard to motility, B rooke (1953) in his study of strains of A. cloacae and Klebsiella (all isolated from human sources, most of them from urine) noted that while all the Klebsiellae were nonmotile, a number of A. cloacae strains were also nonmotile.

Cowan (1954) reviewed the names of the coliform bacteria and asked the Judicial Commission to consider whether Aerobacter Beijerinck 1900 should be placed in the list of nomina generica rejicienda. The Commission should also be asked to determine whether a newly defined genus Aërobacter (not Aerrobacter Beijerinck) should be conserved with the type A. cloacae Jordan, or with a redefined (motile) species A. ärogenes, or whether the genus Cloaca Castellani and Chalmers 1919 should be conserved?

The Editorial Board (1954) published a preliminary statement on the status of the generic names, Escherichia, Klebsiella, Aërobacter and Cloaca. The Enterobacteriaceae Subcommittee $(1954,1958)$ reported on these genera. In the 1958 Report, the Subcommittee proposed to define Klebsiella as consisting of nonmotile, encapsulated bacteria that conform to the definition of the family Enterobacteriaceae and to define Cloaca (Aerobacter) as consisting of motile bacteria that conform to the definition of the family Enterobac- 
teriaceae, and give typical biochemical reactions. The Subcommittee pointed out that cultures of Klebsiella which have been typed were derived largely from respiratory infections and urinary infections in man and from human feces.

Winslow et al. (1919), Weldin (1927), Ruchhoft et al. (1931), Ostermann et al. (1941), Olsen (1942), and Bormán et al. (1944) all noted the difficulties experienced by workers in trying to classify the Klebsiella-Aërobacter group on biochemical tests, particularly sugar fermentations. Ostermann et al. state that they found no single test or group of tests that would distinguish many of their Klebsiella (Friedlander) cultures from those of the coli-aërogenes group and state that it seems not unlikely that much of the confusion still surrounding the Klebsiella (Friedländer) and coliaèrogenes organisms is due to failure to recognize the full significance of variation.

Edwards (1929) isolated strains of Aërobacter from feces, soil, water, and milk and noted that both the Aerrobacter strains and the Friedlander (Klebsiella) strains were rather variable in their fermentative characters.

Parr (1938) noted the difficulty of classifying the coliform bacteria owing to the essentially intergrading nature of the organisms in this group and defined intermediates as coliform organisms which have one or more of the characteristics of Escherichia coli and one or more of those attributed to Aerobacter aërogenes and notes "among the coli formbacteria characters are from time to time lost or those in abeyance are regained." Parr (1939) noted that these intermediate forms either do not conform to the so-called LMViC pattern, or lack power to ferment certain carbohydrates, or produce only acid where the production of acid and gas is considered normal, or display a combination of fermentation characters the reverse of that which normally occurs. It is to be noted that Parr (1936) isolated strains of Aërobacter from feces which had been stored in an ice box for as long as two months.

Stuart et al. (1938) noted that, with some of their 5, 200 cultures isolated from human and bovine feces, from dust of cowbarns, and from milk, growth was more luxuriant at room temperature than at $37^{\circ} \mathrm{C}$ and that cultures (grown in methyl red medium) that produced only acid when grown at $37^{\circ} \mathrm{C}$ for 36 hours produced acid and gas when grown at room temperature for the same period, and also that the methyl 
red reaction varied with temperature of incubation. These irregularities in the methyl red reaction were most noticeable in the strains which either failed to produce gas from lactose at $37^{\circ} \mathrm{C}$ or produced gas at room temperature only.

Stuart et al. (1940) proposed the term "aberrant" coliforms for cultures not fermenting lactose, producing acid only, or requiring more than 48 hours for the production of gas at $37^{\circ} \mathrm{C}$. These strains were isolated from water, soils and cereals. Many of the so-called "aberrant" strains grew abundantly at room temperature but sparsely or not at all when incubated at $37^{\circ} \mathrm{C}$ (in other words they isolated mesophilic strains of Aerobacter).

The Enterobacteriaceae Subcommittee (1958) first gives the biochemical characteristics of the Cloaca (Aërobacter) group and then states. "Although the se biochemical reactions can be considered as typical of the group, there are aberrant cultures, not fermenting lactose, sucrose, rhamnose, sorbitol, raffinose, methyl red positive, Voges-Proskauer, citrate, or $\mathrm{KCN}$ negative. Anaerogenic strains also exist."

My work on the coliform group as a whole has convinced me that a satisfactory classification of the Klebsiella-Aërobacter group cannot be based solely on sugar fermentations. That this fact is generally recognized is shown by the many qualifications found in the literature such as "frequently do not attack"; "may or may not attack"; "many strains ferment"; "usually do not form acid and/or gas." Using a pH meter one can state that fermentation has occurred, but cannot state that a coliform culture is not capable of developing the ability to ferment a given carbohydrate. In carrying out the methyl red and Voges-Proskauer reactions Fouad et al. (1953) have shown the necessity for a chemically defined glucose ammonium phosphate medium.

Some strains of Aerrobacter do not produce gas in lactose broth at $37^{\circ} \mathrm{C}$ but do so at $15-30^{\circ} \mathrm{C}$. Begue and Lichstein (1958) have shown that in Saccharomyces cereviseae the required synthesis of pantothenic acid is accomplished at $30^{\circ} \mathrm{C}$ but in some manner is prevented at $37^{\circ} \mathrm{C}$, i.e. an enzymetemperature system is postulated. Lichstein (-1960) notes "it is becoming increasingly apparent that antagonisms and interactions among nutrients as well as the character of the physical environment influence markedly the nutritional demands of an organism" and "genetic expression is affected by the environment and the presence of a particular gene 
does not necessarily mean that the corresponding character will be expressed."

The ability of non-lactose-fermenting organisms isolated fromfeces to ferment lactose after long cultivation in lactose media has been shown by a number of workers, particularly Kriebel (1934) who draws the conclusion that these strains are closely related to the colon group, possibly as variants, since they tend to dissociate into lactose-fermenting colilike organisms. Tregoning and Poe (1937) found that the production of sucrose-positive variants was readily accomplished in some strains of Escherichia and Aerobacter. DiGirolamo et al. (1958) have shown that strains of $\underline{E}$. coli that did not use arabinose as the sole carbon source did so if seeded on a mixture of rhamnose and arabonise, and noted that the methylpentose is an indicator of the enzyme of arabinose metabolism, which by itself has no inductive property.

Breed (1957) in Bergey's Manual comments on the unsatisfactory position of the Klebsiella-Aërobacter group and notes that no method has been found to differentiate the majority of $\underline{K}$. pneumoniae strains from urinary strains commonly classified as A. aërogenes. He concludes that while awaiting a better solution of the problem it was felt advisable to continue to recognize $\mathbf{A}$. aërogenes (as a species distinct from $\underline{K}$. pneumoniae) and both genera Aerrobacter Beijerinck and Klebsiella. He pointed out that species of Aerrobacter that occur in dairy products are frequently derived from grain and that they are found on panicles of the grass family in open fields.

The Enterobacteriaceae Subcommittee (1958) recommended biochemical methods for differentiation of the genera of the Enterobacteriaceae. Except for gelatin liquefaction at $21^{\circ} \mathrm{C}$, they suggested that tests be carried out at $37^{\circ} \mathrm{C}$ for 2 days. If negative, follow with further incubation at 21 to $25^{\circ} \mathrm{C}$ for 5 days. In our work on the cold-tolerant mesophilic strains of Aërobacter, the above methods have been followed since 1928 at an incubation temperature of $21^{\circ} \mathrm{C}$, since these strains grow poorly or not at all at $37^{\circ} \mathrm{C}$. It is difficult to compare our data with those of previous workers before 1950, since others usually worked with nonmotile cultures and carried out their tests at $37^{\circ} \mathrm{C}$. The methylred test particularly is influenced by the temperature of incubation, since temperature influences the rate of production of acid in the medium. 
Schafler et al. (1959, 1960) obtained through "training" on lactose media and by selection lactose-positive strains of Salmonella which also became cellobiose-positive. An interesting finding was that the appearance of lactose-positive variants from cellobiose-positive variants of Salmonellae was particularly or totally inhibited by succinate or glutamate. Schema et al. (1943) found increasing tolerance of A. aërogenes to sodium pentachlorpentate and noted that in certain cultures gas was no longer formed from arabinose or rhamnose, and that in such cultures the methyl-red test became positive.

That temperature of chemicals can cause gene unstabilization has been shown by Zamenhof and co-workers (1958, 1961). They used a typical strain of $\underline{E}$. coli and a lactose nonfermenting mutant of that strain. A similar situation may well apply to strains of Klebsiella and Aërobacter. There is also the question of growth requirements and I suggest that mesophilic (plant) strains of Aërobacter ingested in the food of an animal (given time) would adapt themselves to their habitat and that the ability to ferment lactose or other properties could be lost. Such a strain later isolated from the urinary tract or from feces might well be identified as Klebsiella or as an intermediate strain. Martinec et al. (196l) discussing the taxonomic status of Serratia marcescens Bizio state that relatively great variability of some strains were observed during the fermentation of carbohydrates and add "it is interesting that the majority of these anomalies was observed in strains isolated from different species of insects."

As a dairy bacteriologist, I have been interested since 1925 in strains of Aërobacter that fermented lactose poorly or not at all at $37^{\circ} \mathrm{C}$. They were first isolated from creamery water supplies contaminated by soil. Since in a creamery water supply it is as important to eliminate soil contamination as to detect fecal contamination, in routine examination for the coliform group lactose-broth tubes were inoculated in duplicate at $21^{\circ} \mathrm{C}$ and at $37^{\circ} \mathrm{C}$. This procedure, also applied to milk and milk products, led to the isolation from water, milk, cream, poor quality butter, gassy cheese, and ice cream, of strains of Aërobacter whose optimum temperature ranged from $20^{\circ} \mathrm{C}$ to $30^{\circ} \mathrm{C}$, that grew well at $15^{\circ} \mathrm{C}$ and grew slowly at $4^{\circ} \mathrm{C}$ (1931).

Grimes (1934) concluded that while it is now usual to 
carry out the test for Escherichia and Aërobacter from water and dairy products at $37^{\circ} \mathrm{C}$ the test should also be carried out also at $21^{\circ} \mathrm{C}$, otherwise the Aërobacter group, although present, may not be identified. These cold-tolerant mesophilic strains of Aërobacter have been isolated by many workers from soil, grasses, ears and panicles of cereal crops, milk, cream, poor quality butter, gassy cheese, ice cream, creamery and farm water supplies and dairy farm equipment, chilled meat and crabmeat.

A characteristic of these strains of Aerobacter is their poor growth or lack of growth in lactose broth at $37^{\circ} \mathrm{C}$. Thomas and co-workers (1958) state that out of 1040 cultures isolated from raw milk and farm dairy equipment which fermented lactose with the formation of acid and gas to $30^{\circ} \mathrm{C}$, 473 (nearly 50\%) failed to produce gas from lactose in two days at $37^{\circ} \mathrm{C}$.

Although this paper is concerned mainly with mesophilic strains of Aerrobacter I have also worked on the strains that grow best at $37^{\circ} \mathrm{C}$, likewise strains of Escherichia and various intermediate strains. I am of the opinion that while one can state that a particular strain is capable of a particular fermentation, it cannot be said that it is incapable of fermenting that substance. Whether or not fermentation occurs depends on the original environment, medium used, temperature of incubation and length of time of incubation.

The growth medium and the temperature of incubation may also influence motility. I find peptone broth the best medium for determining motility, the culture to be incubated for 24 hours at its optimum temperature. One does not get as good results with lactose broth, for the strains of Acrobacter grow plumper and larger, and in the motility test they are found to be sluggishly motile or nonmotile.

I am in agreement with Hormaeche and Edwards (1960) that capsules and slime formation are of no value in differentiation since the related strains are not constant in the se properties. In our routine work (incubation temperature $21^{\circ} \mathrm{C}$ ), streaking or plating on Levine media from lactose broth cultures showing acid and gas at $21^{\circ} \mathrm{C}$ in 24 to 48 hours the mucoid strains are readily separated from the nonmucoid strains, but I have not found it possible definitely to separate them by biochemical tests. The mucoid strains will cause ropiness in milk and give sliminess in glucose, lactose, and sucrose broth and more or less slimi- 
ness in galactose, raffinose, sorbitol, xylose and glucerol broth. There is no correlation between mucoid growth or nonmucoid growth and the liquefaction of gelatin.

In classifying Klebsiellae and Aerobacteres one is between Scylla and Charybdis, since on the one hand it is possible to simplify by restricting the number of tests, e.g. relying on IMViC and the fermentation of lactose and glucose, or on the other hand to complicate to the point of absurdity by differentiating on numerous fermentation and other tests. There is the further complication that the influence of medium, growth temperature and length of time of incubation has not always been fully recognized. Alford (1960) and Schultze et al. (1960) support our contention of the importance of incubation temperature when carrying out biochemical tests. Taylor's question (1959) "Why Christen a Salmonella?". is pertinent here, and the same question can be asked also regarding the Klebsiella-Aërobacter group. The cold-tolerant mesophilic strains of Aërobacter especially are to be regarded as an adaptable group capable of changing to meet changes in their environment (given time) whether it be biological or biochemical.

In discussing the legitimacy of the generic name Klebsiella to include both Klebsiella and Aërobacter, the report of the Coli-Aerogenes (1956) Subcommittee of the Society for Applied Bacteriology (1956) states "since the generic name Klebsiella has priority over Aerrobacter, the aerogenes organism not only falls into the genus Klebsiella but, strictly, also loses its specific name. However, if the Rules of the Bacteriological Code (1948) are strictly applied, the correct names for many coli-aerogenes bacteria would be so unfamiliar as to cause confusion and error, and it will be necessary to ask for official opinions to conserve suitable names against earlier. The views experssed by Cowan (1954) concerning names for coliform organisms and his paper "Nonconformism in Nomenclature" (1959) are also relevant.

Hormaeche and Edwards (1960) have discussed the difficulty of classifying the bacteria of the Klebsiella-Aerrobacter group. They proposed a new genus Enterobacter with the type species Enterobacter cloacae based on Bacillus cloacae Jordan (1890) and requested that the term Enterobacter Hormaeche and Edwards be placed in the list of conserved bacterial generic names and that Enterobacter cloacae Jor- 
dan comb. nov. (‥ cloacae Jordan, 1890) be designated as its type species. This request of Hormaeche and Edwards deserves careful consideration, but it accepts in general only those strains of Aërobacter with an optimum temperature $37^{\circ} \mathrm{C}$, and rejects the cold-tolerant me sophilic strains of Aërobacter of Grimes and Hennerty (1931). Ewing and Edwards (1960) state "that at present the Aërobacter group is divisible into three subgroups corresponding to the species $A$. cloacae, $\underline{A}$. ärogenes and $\underline{A}$. liquefaciens Grimes (1931)."

Hormaeche and Edwards (1958) make a valuable contribution in their observations on the genus Aërobacter with respect to the separation of Aërobacter from Klebsiella on the basis of motility and the urease and ornithine decarboxylase tests. They note that nonmotile variants of otherwise typical cultures are known to occur, likewise aberrant and intermediate strains. They state that there are at least two well-defined species-A. aèrogenes and A. cloacae-and list their biochemical characteristics. I am of the opinion that sanitary and food bacteriologists would be in agreement in desiring that the generic name Aërobacter be retained even though Klebsiella has precedence. Classification is not intended to fit a concept of static genera and species. With the development of more and better taxonomic methods, particularly serological methods, the interrelationships of the strains that comprise the Klebsiella-Aërobacter group are now somewhat better realized. Can Klebsiella be differentiated from Aerobacter while acknowledging the adaptability of the latter group to adjust itsel to its environment, resulting in a variety of intermediate strains, which may also be termed "variant" or "aberrant"?

The description of the genus Klebsiella, as given by the Enterobacteriaceae Subcommittee (1958) and in Bergey's Manual (1957), I would amend as follows: Nonmotile short rods, Gram-negative, encapsulated in the mucoid phase, conforming to the definition of the family Enterobacteriaceae, methyl-red negative, Voges-Proskauer positive, gelatin not liquefied, citrates utilized as sole source of carbon, nitrites produced from nitrates, sodium malonate positive, capable of fermenting glucose, lactose, sucrose, mannitol, salicin, and growing in KCN medium. The type species is Klebsiella pneumoniae. Encountered frequently in the respiratory, intestinal and urogenital tracts of man'and recognized 
as one of the causes of mastitis in cattle (Barnes, 1953; Buntain and Field, 1953; Esterbrooks and Plastridge, 1956; Guillot et al. 1961; Smith and Henderson, 1934; White, 1957; The type species represents the strains of the group that are adjusted to a human or animal habitat, and may be more or less pathogenic.

As to the value of biochemical tests in distinguishing $\underline{A}$. cloacae from A. aerrogenes, the Enterobacteriaceae Subcommittee (1958) give the biochemical characteristics of Cloaca (Ärobacter) and state "although these biochemical characteristics can be considered as typical, there are aberrant cultures not fermenting lactose, sucrose, rhamnose, sorbitol, raffinose, methyl-red positive, Voges-Proskauer, citrate or KCN negative, Two biochemical types can be differentiated. Type A does not generally ferment inositol nor glycerol, and when doing so does not produce gas in four days; it is arginine positive, lysine negative and liquefies gelatin. Type B promptly ferments with gas inositol and glycerol, is arginine negative, lysine positive and about hals the strains do not liquefy gelatin."

Breed (1957) states "usually motile" gelatin colonies "thin, circular, bluish, translucent" (no mention of liquefaction). Gelatin stab-"slow liquefaction, liquefying power sometimes lost."

I regard a nonmotile A. cloacae strain as a variant of A. ä̈rogenes Beijerinck, 1900 , i.e. a Klebsiella strain; a motile A. cloacae that does not liquefy gelatin as not properly identified and the motile A. cloacae strain that liquefies gelatin, more or less slowly, as a variant of $\mathrm{A}$. lipolyticus nom. nov. described below.

Aerrobacter is defined as follows: motile, Gram-negative rods, mucoid phase common in media containing lactose, conforming to the definition of the family Ente robacteriaceae, methyl-red negative, Voges-Proskauer positive, uric acid, citric acid and citrates utilized as sole source of carbon, nitrites formed from nitrates, fermenting with the production of acid and gas-glucose, levulose, galactose, lactose, sucrose, maltose, cellobiose, mannitol, raffino e, sorbitol, inositol, rhamnose, arabinose, xylose, glycerol, salicin, aesculin, a-methyl glucoside; positive for arginine dihydrolase, lycine and ornithine decarboxylases; sodium formate and sodium malonate positive. Growth in $\mathrm{KCN}$ medium. Phenylalanine deaminase negative. Dulcitol, 


\section{B ACTERIOLOGICAL NOMENCLATURE}

AND TAXONOMY

inulin, potato starch, destrin may or may not be fermented. Indole test usually negative.

These biochemical reactions are typical for the strains that comprise the cold-tolerant mesophilic strains, optimum temperature, $20^{\circ} \mathrm{C}$ to $30^{\circ} \mathrm{C}$; good growth at $15^{\circ} \mathrm{C}$. growth at $4^{\circ} \mathrm{C}$; poor or no growth at $37^{\circ} \mathrm{C}$.

Soil and plant strains, isolated from soil, grasses, cereals, water, milk and milk products, and cold-stored meat. Cause of ropy milk. Aërobacter lipolyticus nom. nov. liquefies gelatin. Pectin not liquefied.

A strain with the same biochemical characteristics, but incapable of liquefying gelatin, has been named Aërobacter hibe rnicum.

The name Aërobacter liquefaciens Grimes and Hennerty 1931 is a later homonym of Aërobacter liquefaciens Beijerinck 1900, hence illegitimate. The name Aerobacter lipolyticus nom. nov. is proposed to replace $\underline{A}$. Liquefaciens Grimes and Hennerty. A detailed description is given herewith.

\section{Aërobacter lipolyticus nom. nov.}

Synonym: Aërobacter liquefaciens Grimes and Hennerty 1931, not A. liquefaciens Beijerinck 1900.

Morphology: Rods, 0.75-1.0 x 1.0-2 $\mu$, motile, possessing pertrichous flagella, Gram-negative, aerobic, facultative, nonspore-forming.

Nutrient gelatin: Two days at $21^{\circ} \mathrm{C}$. Punctiform, entire dirty greyish colonies, gelatin liquefied.

Nutrient gelatin stab: Two days at $21^{\circ} \mathrm{C}$. Filiform growth with liquefaction. Five to seven days - above $10 \%$ lique faction, infundibuliform. Two to three weeks-around $40 \%$ liquefaction.

Tryptone dextrose agar: Two days-colonies, circular, smooth, moist, glistening, greyish-white, viscid, convex, opaque, raised, entire.

Tryptone dextrose agar slant: Two days - abundant greyishwhite growth, smooth, moist, glistening, opaque, viscid.

Nutrient broth: Good growth in 24 hours, turbid.

Levine medium: One to two days - good, nonchromogenic growth. Colonies or streak-smooth, glistening, opaque, viscid. 
Potato slope: Two to five days-good growth, smooth, moist, glistening, opaque, viscid, muddy grey to brownish grey colour.

\section{Biochemical Tests at $20-30^{\circ} \mathrm{C}$}

Methyl-red: Negative.

Voges-Proskauer test: Positive.

Uric acid media: Two days-good growth. $\mathrm{pH}$ 4.4-5.0.

Koser's citrate medium: Two days-good growth.

Hydrogen sulfide: Lead acetate filter paper strip-Negative.

Bismuth liquor technique. 1938. J. Bact. 35:183. Definite

blackening around the top of the medium and along the line of the stab.

Nitrates reduced to nitrites.

Indol: Usually negative (positive strains found).

Catalase: Positive.

Diastatic action: Negative.

Milk: Acid coagulation, ropiness, $\mathrm{pH} 5.3$ in two to three days. Acidity 0.5 to $0.6 \%$ lactic acid.

The following are fermented with production of acid and gas, with $\mathrm{pH}$ dropping to 5.0 or lower in two to four days: Lactose, sucrose, fructose, galactose, maltose, rhamnose, arabinose, cellobiose, aesculin.

$\mathrm{pH}$ dropping to less than 5.5 but not lower than 5.1 : Mannitol, inositol, adonitol, xylose, raffinose, a-methyl glucoside, salicin.

$\mathrm{pH}$ dropping to 6.6 but not lower than 5.6: Sorbitol, glycerol, amygdalin.

Glucose: Drops to $\mathrm{pH} 5.5$ in two days and is around 7.0 in four days.

Dulcitol may or may not be fermented; when fermented, $\mathrm{pH}$ varied from 5.5 to 6.5 .

Erythritol: Not fermented.

Mucoid phase common in media containing glucose and lactose.

Inulin: Usually fermented, $\mathrm{pH} 6.3$ (average).

Dextrin: May or may not be fermented; when fermented, $\mathrm{pH} 6.4$ (average).

Starch: May or may not be fermented; when fermented, pH 6.0 (average).

Sodium malonate: Positive, $\mathrm{pH} 8.4$ (average). One negative strain found. 
Sodium hippurate: May be negative or positive, $\mathrm{pH} 6.2$ (average).

Sodium formate: Positive, gas production, $\mathrm{pH} 8.4$ (average). KCN: Positive.

Asparagine: Positive, pH 8.0 (ave rage).

Arginine dihydrolase: Usually positive.

Lysine decarboxylase: Positive.

Phenylalanine deaminase: Negative.

Ornithine decarboxylase: Positive

Growth in $7.5 \%$ sodium chloride solution.

\section{REFERENCES}

Ainsworth, G.C. and S.T. Cowan. 1954. Rules of nomenclature for fungi and bacteria. Jour. Gen. Microbiol. $10: 465$.

Alford, J.A. 1960. Effect of incubation temperature on biochemical tests in the genera Pseudomonas and Achromobacter. Jour. Bact. 79:591.

Allen, L.A. and J. Harrison. 1936. The characters of some coliform bacteria isolated from grass silage. Annals Appl. Biol. 23:538.

, G.J. Watson and W.G. Ferguson. 1937.

A study of the chemical and bacteriological changes occurring in grass silage. Jour. Agric. Sci. 27:271.

Andrey, G.C. and W.C. Frazer. 1959. Psychrophilic bacteria held two days in farm bulk cooling tanks. Jour. Dairy Sci. 42:1781-1784.

Barnes, L.E. 1953. Four cases of bovine mastitis caused by Klebsiella pneumoniae. Vet. Record 65:163.

Begue, W.J. and H.C. Lichstein. 1959. Increased nutritional requirements of Saccharomyces cerevisae as a result of incubation at $38^{\circ} \mathrm{C}$.

Beijerinck, M.W. 1900. Schwefelwasserstoffbildung in den Stadtgräben und Aufstellung der Gattung Aërobacter. Zentralbl. Bakt., Abt. 2, 6:193-206.

Bergey's Manual of Determinative Bacteriology. 1957. Williams and Wilkins Co., Baltimore. 7th ed. p. 333.

Borman, E.K., C.A. Stuart and C. M. Wheeler. 1944. Taxonomy of the family Enterobacteriaceae. Jour. Bact. 48: 351 . 
Brooke, M.S. 1953. The differentiation of Aerobacter aërogenes and Aërobacter cloacae. Jour. Bact. 66:721.

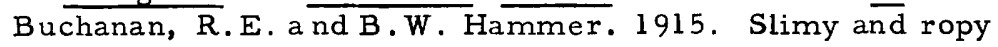
milk. Iowa Agric. Exp. Sta. Res. Bull. No.22.

, R. St. John-Brooks and R.S. Breed. 1948. International Bacteriological Code of Nomenclature. Jour. Bact. 55:287.

Buntain, L.A. and H.J. Field 1953. An outbreak of mastitis in cattle due to infection with an organism of the Friedlander group. Vet. Record 65:91.

Chen, C.C. and L.F. Rettger. 1920. Coli-aerogenes group of bacteria. Jour. Bact. 5:253.

Coli-Aerogenes Subcommittee. 195 $\overline{6}$. Report of the Coliaerogenes (1956) Subcommittee of the Society for Applied Bacteriology on the nomenclature of the coli-aerogenes bacteria. Jour. Applied Bact. 19:108.

Cook, K.A. 1958. A polarly flagellated member of the Ente robacteriaceae. Jour. Appl. Bact. 21:1.

Cowan, S.T. 1954. A review of the names for coliform organisms. Internatl. Bull. Bact. Nomen. and Taxon. 4:119.

- 1959. Nonconformism in nomenclature. Internatl. Bull. Bact. Nomen. and Taxon. 9:131.

Dahlberg, A.C. 1946. The relationship of the growth of all bacteria and coliform bacteria in pasteurized milk held at refrigeration temperatures. Jour. Dairy Sci. 29:651.

DiGirolamo, M., F. Magliocco, A. Schiesser and G. Tecce. 1958. Utilizzazione del D-arabinose in E. coli. Giornale di Microbiologia 5:111.

Esterbrooks, H.L. and M.N. Plastridge. 1956. Acute Klebsiella (capsulated coliform) mastitis. Jour. Amer. Vet. Assoc. 128:502.

Eddy, B.P. and A.G. Kitchell. 1959. Cold-tolerant fermentative Gram-negative organisms from various chilled meats. Jour. Appl. Bact. 22:57.

Editorial Board. 1954. Status of the generic names Escherichia, Klebsiella, Aërobacter, and Cloaca. Preliminary Statement. Internatl. Bull. Bact. Nomen. and Taxon. 4:159.

Edwards, P.R. 1929. Relationships of the encapsulated bacilli with special reference to Bacterium aerogenes. Jour. Bact. 17:339. - 1957. Private communication. 
and W.H. Ewing. 1955. Identification of Enterobac-

teriaceae. Burgess, Minneapolis.

and M.A. Fife. 1955. Studies on Klebsiella-

Aerobacter group. Jour. Bact. 70:382.

Enterobacteriaceae Subcommittee. 1954 . The Klebsiella

(Klebsiella-Aerogenes) group. Internatl. Bull. Bact.

Nomen. and Taxon. $\underline{4}: 75$.

- 1958. Report of the Enterobacteriaceae Subcommit-

tee of the Nomenclature Committee of the International

Association of Microbiological Societies. Internatl. Bull.

Bact. Nomen. and Taxon. 8:25.

Escherich, T. 1885. Die Darmbakterien des Neugeborenen und Säuglings. Fortschritt d. Med. 3:515,574.

Fouad, M.T.A. and T. Richards. 1953. The use of glucose inorganic salts media in the classification of the coliaerogenes bacteria. (The methyl-red and VogesProskauer reactions). Proc. Soc. Appl. Bact. 16:112.

Garradd, E.H. 1943. Coliform organisms found in private wells. Conn. Jour. Publ. Health. (Feb. issue)

Greene, V.W. and J.J. Jereski. 1954. Influence of temperature on the development of several psychrophilic bacteria of dairy origin. Appl. Microbiol. 2:110.

Griffin, A.M. and C.A. Stuart. 1940. An ecological study of the coliform bacteria. Jour. Bact. 40:83.

Grimes, M. 1934. The detection of the EscherichiaAerobacter group in butter. Jour. Dairy Sci. 17:11. and A.J. Hennerty, 1931. A study of bacteria belonging to tbe subgenus Aerrobacter. Sci. Proc. Roy. Dublin Soc. (Ireland) 20(NS):89.

Guillot, G. and co-workers. 1961. Étude d'une Klebsiella pneumoniae pathogène isòlée chez le chien. Abstract 636. The Vet. Bull. $31: 112$.

Hammer, B.W. and M. W. Yale. 1932. Development of the Escherichia-Aerobacter group of bacteria in butter. Jour. Dairy Sci. 15:199.

Hormaeche, E. and P.R. Edwards. 1958. Observations on the genus Aerobacter with a description of two species. Internatl. Bull. Bact. Nomen. and Taxon. $8: 111$. and - 1960. Proposal for the rejection of the generic name Cloaca Castellani and Chalmers and proposal of Enterobacter as a generic name with designation of type species and of its type culture. Internatl. Bull. Bact. Nomen, and Taxon. 10:71. 
Jordan. General Bacteriology. 11 th ed. p. 281 . and Falk. 1928. The newer knowledge of bacteriology and immunology. p. 389.

Kampe, A. 1953. On coliform bacteria in raw milk. Internatl. Dairy Cong. The Hague. 2:148.

Kauffmann, F. 1954. Enterobacteriaceãe. 2nd ed. Munksgaard, Copenhagen. and P.R. Edwards. 1952. Classification and nomenclature of Enterobacteriaceae. Internatl. Bull. Bact. Nomen. and Taxon. $2: 2$.

Kliebel, R. M. 1934. A comparative bacteriological study of a group of nonlactose fermenting bacteria isolated from stools of healthy food-handlers. Jour. Bact. 27:357.

Kon, P.M. 1933. Coliform organisms in milk and faeces. Jour. Dairy Res. $\underline{4}: 206$.

Leifson, E. 1933. The fermentation of sodium malonate as a means of differentiating Aerobacter and Escherichia. Jour. Bact. 26:329.

Levine, M. 1918. A statistical classification of the coloncloacae group. Jour. Bact. 3:253. - 1921. Iowa Engr. Exp. Sta. Bull. No.62. Ames.

Lichstein, H.C. 1960. Microbial nutrition. Ann. Rev. Microbiol. 14:17.

Malcolm, J.F.1933. The occurrence of coliform bacteria in milk. Jour. Dairy Res. 5:15. - 1939. The enrichment of Aerogenes-Cloacae types in milk held at low temperatures. Jour. Dairy Res. $10: 410$.

Marth, E.H. and W.C. Frazier. 1957. Bacteriology of milk held at farm bulk cooling tank temperatures. III. Psychrophilics found and their growth. Jour. Milk and Food Tech. 20:93.

Martinec, T. and M. Kocur. 1961. The taxonomic status of Serratia marcescens Bizio. Internatl. Bull. Bact. Nomen. and Taxon. 11:7.

Murray, J.G. 1953. A comparison of $30^{\circ} \mathrm{C}$ and $37^{\circ} \mathrm{C}$ as incubation temperatures in presumptive coli-aerogenes test for raw and pasteurized milk. Jour. Appl. Bact. 16:24.

Nava, G.C. 1959. Sulla composizione chimica degli antigeni della Salmonella. Giornale di Microbiol. 7:123. 
Olsen, E.M. 1942. On coliform bacteria in milk. Handrup and Wunsch. Copenhagen.

O'Neill, B.J. and M. Grimes. 1947. A study of ice cream sold in Cork City. Jour. Dept. Agric., Ireland. 44:47.

Ostermann, E. and L.F. Rettger. 1941. A comparative study of organisms of the Friedlander and coli-aerogenes group. Jour. Bact. 42:699.

Parr, L.W. 1936. Sanitary significance of the succession of coli-aerogenes organisms in fresh and stored feces. Amer. Jour. Pub. Health 26:39. . 1938. Coliform intermediates in human feces. Jour. Bact. 36:1.

- 1939. Coliform bacteria. Bact. Rev. 3:1

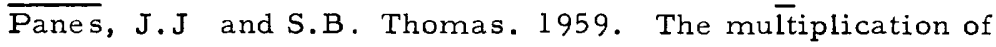
coli-aerogenes bacteria in milk stored at $3-5^{\circ} \mathrm{C}$. Jour. Appl. Bact. 22:272.

Rogers, L.A., W.M. Clark and H.A. Lubs. 1918. The characteristics of bacteria of the colon type occurring in human feces. Jour. Bact. $3: 231$.

Ruchhoft, C.C., J.C. Kallas, B. Churn and E.W. Coulter. 1931. Coli-aerogenes differentiation in water analysis. Jour. Bact. 22:125,407.

Sarles, W.B. and B.W. Hammer. 1933. Species of Escherichia-Aerobacter organisms responsible for some defects in dairy products. Jour. Bact. 25:461.

Schafler, S, and L. Mintzer. 1960. Acquisition of lactosefermenting properties by Salmonella. Jour. Bact. $\underline{78}$ : $159-163$.

, and C. Schafler. 1960. Acquisition of lactose-fermenting properties by Salmonella. Jour. Bact. 79:203.

Schema, B.F. and J.W. Appling. 1943. The increased resistance of Aerobacter aerogenes to sodium pentachloropentate. Jour. Bact. 45:573.

Schultze, W.D. and J.C. Olson. 1960. Studies on psychrophilic bacteria. Part 2. Psychrophilic coliform bacteria in stored commercial dairy products. Jour. Dairy Sci. 43:351.

Smith, F.R. and J.L. Henderson, 1934. Escherichia coli in mastitis. Jour. Dairy Sci. 17:799.

Stuart, C.A., A. M. Griffin, and $\bar{M}$. E. Baker. 1938. Relationships of coliform organisms. Jour. Bact. 36: 391 . 
F.L. Mikle and E.K. Borman. 1940, Suggested grouping of slow lactose fermenting coliform organisms. Amer. Jour. Pub. Health 30:499.

Taylor, Joan. 1959. Why christen a Salmonella? Internatl. Bull. Bact. Nomen, and Taxon. 9:159.

Thomas, S.B. 1953. Ropiness in milk. Dairy Industry $18: 401$.

- 1955. Coli-aerogenes bacteria in raw milk. Jour. Appl. Bact. 18:331.

, P.M. Hobson and K. Elson. 1958. Coli-aerogenes bacteria from farm dairy equipment and raw milk. Jour. Appl. Bact. 21:58.

. 1958. Psychrophilic microorganisms in milk and dairy products. Dairy Sci. Abstr. 20:355, 447 .

, D. L. B rown, N.B. Bebbington, E. Mackenzie and M. Beavan. 1957. Examination of milk by the coliaerogenes test on violet-red bile agar. Dairy Industry $\underline{22}: 821$.

, J.A. Charlton, E. Griffiths, M. McClintook and

R.G. Druce. 1957. Coli-aerogenes bacteria in farm milk supplies evaluation of the coli-aerogenes test at $30^{\circ} \mathrm{C}$. Dairy Industry $22: 200$.

and P.M. Hobson. 1955. Coli-aerogenes bacteria isolated from ears and panicles of cereal crops. Jour. Appl. Bact. 18:1. and R.G. Druce. 1959. Coli-aerogenes bacteria in farm water supplies. Jour. Appl. Bact. 22:32.

, and E.R. Bird. 1959. Psychrophilic bacteria in milk. Rept. 15th Internatl. Dairy Congr., London. p. 334 .

F.G. Jones and P.N. Franklin. 1951. The classification of coli-aerogenes bacteria isolated from farm water supplies. Proc. Soc. Appl. Bact. 14:45. and J. McQuillin. 1952. Coli-aerogenes bacteria isolated from grasses. Proc. Soc. Appl. Bact. 15:41.

Tregoning, J.J. and C.F. Poe. 1937. Production of variants of the colon and aerogenes groups in different media. Jour. Bact. 34:465.

Weldin, J.C. 1928. The colon-typhoid group of bacteria and related forms. (Relationships and Classification.) Iowa State Coll. Jour. Sci. $1: 121$. 
BACTERIOLOGICAL NOMENCLATURE AND TAXONOMY

White, P. 1957. An outbreak of mastitis in cattle and death of calves due to infection with an organism of the Friedlander group (Klebsiella). Vet. Record 69:566.

Winslow, C.E.A. and I.J. Kliger. 1916. Studies on the classification of the colon-typhoid group. Jour. Bact. $\underline{1}: 81$.

and W. Rothberg. 1919. Studies on the classification of the colon-typhoid group of bacteria with special reference to their fermentation reactions. Jour. Bact. 4:429.

Yale, M. W. 1933. The Escherichia-Aerobacter group of bacteria in dairy products. Jour. Dairy Sci. 16:481.

Zamenhof, S. and R. Giovanni, 1958. Study of survival of unstable strains of Escherichia coli. Jour. Bact. 75:514. . 1961. Gene unstabilization induced by heat. Jour. Bact. $81: 111$. 
